\title{
Evaluating internal and external markers versus fecal sampling procedure interactions when estimating intake in dairy cows consuming a corn silage-based diet
}

\author{
A. V. Velásquez, ${ }^{1}$ G. G. da Silva, D. O. Sousa, C. A. Oliveira, C. M. M. R. Martins, P. P. M. dos Santos, \\ J. C. C. Balieiro, F. P. Rennó, and R. S. Fukushima \\ Departamento de Nutrição e Produção Animal, Faculdade de Medicina Veterinária e Zootecnia, University of São Paulo, Av. Duque de Caxias, \\ 225-Pirassununga, SP 13630-900, Brazil
}

\begin{abstract}
Feed intake assessment is a valuable tool for herd management decisions. The use of markers, either internal or external, is currently the most used technique for estimating feed intake in production animals. The experiment used 10 multiparous Holstein cows fed a corn silage-based diet, with 55:45 forage-to-concentrate ratio, the average fecal recovery (FR) of $\mathrm{TiO}_{2}$ was higher than FR of $\mathrm{Cr}_{2} \mathrm{O}_{3}$, and both FR were more than unity. With internal markers, acetyl bromide lignin and cutin FR were lower than unity, and average FR for indigestible neutral detergent fiber (iNDF) and indigestible acid detergent fiber (iADF) was 1.5. The FR was unaffected by the fecal sampling procedure and appears to be an intrinsic property of each molecule and how it interacts with digesta. Of the 2 external markers, only $\mathrm{Cr}_{2} \mathrm{O}_{3}$ produced accurate fecal output (FO) estimates and the same happened to dry matter digestibility (DMD) when iNDF and iADF were used. Estimates for DMD and FO were affected by sampling procedure; 72-h bulk [sub-sample from total feces collection (TFC)] sampling consistently produced accurate results. The grab (sub-samples taken at specific times during the day) sampling procedures were accurate when using either of the indigestible fibers (iNDF or $\mathrm{iADF}$ ) to estimate DMD. However, grab sampling procedures can only be recommended when concomitant TFC is performed on at least one animal per treatment to determine FR. Under these conditions, $\mathrm{Cr}_{2} \mathrm{O}_{3}$ is a suitable marker for estimating FO, and iNDF and $\mathrm{iADF}$ are adequate for estimating DMD. Moreover, the $\mathrm{Cr}_{2} \mathrm{O}_{3}+\mathrm{iADF}$ marker pair produces accurate dry matter intake estimates and deserves further attention in ruminant nutrition studies. The method of dosing the external markers is extremely important and greatly
\end{abstract}

Received June 3, 2017.

Accepted December 29, 2017.

${ }^{1}$ Corresponding author: alejandrovavel@usp.br affects and determines results. Whichever the method, it must allow the animals to display normal feeding behavior and not affect performance. The grab sampling procedures can replace TFC (once FR is established), which may open new possibilities for pasture-based or collectively housed animals.

Key words: chromic oxide, intake, indigestible fiber, lignin, titanium dioxide

\section{INTRODUCTION}

Dry matter intake is a key determinant of nutrient intake and may be an index of the efficiency with which nutrients are metabolized; therefore, it is the major factor influencing animal performance. Many different strategies have been used over the years to estimate voluntary DMI in ruminants. Behavioral studies (time and rate of intake, mass of bite; Silva et al., 2004; Costa et al., 2011), before and after grazing pasture measurements (Poppi et al., 1987), and multiple regression equations that consider different variables believed to affect intake have been commonly used approaches.

The use of markers is currently the most widely used technique to estimate DMI in ruminants. Markers are indigestible substances that are not secreted or absorbed by the animal, have passage rates similar to feeds, can be recovered completely after ingestion, and allow for practical and precise chemical analysis (Fahey and Jung, 1983). According to Merchen (1993), none of the substances that are used as markers in ruminant digestion studies meet all of the requirements, but some are adequate enough to produce important data for the advancement of research.

The marker technique to estimate intake uses an external marker to estimate fecal output (FO) and an internal marker (naturally occurring in feedstuffs) to estimate dry matter digestibility (DMD). Intake is then calculated by dividing FO by the indigestibility $(1$ - DMD) of the feed. The main criticisms of this technique are the difficulty and labor of feeding the 
external markers twice a day, for several days; the need for excessive interaction between animals and people, which may affect intake; and the intensive labor and high cost of feces sample collection.

Total feces collection (TFC) is regularly used in intake studies as the standard to which estimates are compared and as the source of bulk samples for later analysis. The recommended number of days for TFC ranges from 7 to $10 \mathrm{~d}$ (Schneider and Flatt, 1975) to 3 to $5 \mathrm{~d}$ (Ferreira et al., 2008), with authors reporting no significant differences for digestibility estimates. Just as number of days for TFC can be reduced, different fecal sampling designs have been proposed to reduce the short-term bias of estimates (Langlands et al., 1963), which accounts for the inconsistencies of obtaining the feces samples. In this approach, grab samples collected at specific times during the day, either after spontaneous excretion or collected directly from the rectum, are composited to make up the daily samples. Sampaio et al. (2011a) compared 9 different fecal sampling designs and reported that a 4-d sampling period, in which 4 daily grab samples are taken, distributed along the whole day or just during the diurnal period, will produce accurate estimates.

From the above, it can be hypothesized that the combination of internal and external markers, with fecal sampling designs that produce composite grab samples over 3 to $4 \mathrm{~d}$ of collection period, should result in accurate estimates for DMD, FO, and DMI in dairy cows consuming a corn silage-based diet.

The objectives of the experiment were to test the accuracy of internal markers, acetyl bromide lignin (ABL), cutin, indigestible neutral detergent fiber (iNDF), and indigestible acid detergent fiber (iADF) for estimating DMD; the external markers $\mathrm{Cr}_{2} \mathrm{O}_{3}$ and $\mathrm{TiO}_{2}$ for estimating FO; the combination of internal and external markers for estimating DMI; and to compare 3 different sampling designs against TFC.

\section{MATERIALS AND METHODS}

The experiment was conducted at the Dairy Cattle Research Laboratory of the Animal Nutrition and Production Department at the University of São Paulo. The experiment was approved by the Ethics Committee for Animal Use (CEUA) of the University of São Paulo (approval number: CEUA 24420603114). No animals were harmed or became ill during the experiment.

\section{Animals, Diet, and Experimental Design}

Ten multiparous Holstein cows (average \pm SD; parity: $1.2 \pm 0.4$ lactations; DIM: $123 \pm 53.7$ d; milk yield;
$25.5 \pm 3.8 \mathrm{~kg} / \mathrm{d}$; BW: $616.7 \pm 67.2 \mathrm{~kg}$ ) were used for the study. The mouth, tongue, and teeth of all cows were examined before starting the experiment to guarantee absence of wounds or abnormalities that could compromise feed intake. Cows were housed in a covered, concrete floor freestall, divided by gates into individual stalls, each of which had a feed bunk, access to clean water, and a sand-covered bed. Cows were milked twice a day (0700 and $1500 \mathrm{~h}$ ) and milk yield was recorded during the experimental period.

All cows received a corn silage-based diet, with 55:45 forage-to-concentrate ratio. Daily allowances of the TMR, plus $10 \%$ of calculated DMI (to guarantee orts), were fed in 2 equal portions at 0800 and 1600 $\mathrm{h}$, to represent a natural diurnal feeding pattern of cattle. Subsamples of individual feeds and TMR were taken on Mondays, Wednesdays, and Fridays for DM determination [drying in a forced-draft oven (Solab Cientifica, Piracicaba, SP, Brazil) at $55^{\circ} \mathrm{C}$ for $3 \mathrm{~d}$ ]. Orts were collected daily so that ad libitum intake could be determined as the difference between the DM offered and refused. The concentrate was composed of coarsely ground corn grains (50.9\% of total grain mix $\mathrm{DM})$, soybean meal (25\% of total grain mix DM), and whole roasted soybeans ( $8.8 \%$ of total grain mix DM), cottonseed meal (10.2\% of total grain mix DM), and mineral mix (4.4\% of total grain mix DM). Cottonseed meal was added to replace part of the soybean meal, due to its high contents of cutin (from added cotton hulls). Increasing the cutin concentration of the diet was desirable to facilitate analysis and decrease variability of results. Composition of silage, concentrate, and TMR are shown in Table 1.

The experiment ran for $19 \mathrm{~d}$ (day regarded as the 24-h period from 0800 to $0800 \mathrm{~h}$ ). The experimental period consisted of 3 phases: d 1 to 5 were allocated to adaptation of the animals to the diet; $10 \mathrm{~d}$ (d 5 to 15) of marker excretion stabilization and the final $4 \mathrm{~d}$ (d 16 to 19) were for sample collection. The animals were adapted to the experimental conditions during 14 $\mathrm{d}$ before the experimental period. The 10 cows were distributed into a split-plot design, with the main plot (markers) being completely randomized and the sampling designs as sub-plots.

\section{Markers}

Four internal markers (ABL, cutin, iNDF, and iADF) were used to estimate DMD and 2 external markers $\left(\mathrm{Cr}_{2} \mathrm{O}_{3}\right.$ and $\left.\mathrm{TiO}_{2}\right)$ were used to estimate FO. The 8 combinations (1 internal marker and 1 external marker) derived from these 6 markers were used to estimate voluntary DMI. Estimates of DMD, FO, and DMI were 
compared against their reciprocal total-tract apparent digestibility (TTAD), real fecal output (RFO), and real dry matter intake (RDMI) values, respectively.

Internal markers are naturally occurring indigestible fractions of feedstuffs. External markers, in this case $\mathrm{Cr}_{2} \mathrm{O}_{3}$ and $\mathrm{TiO}_{2}$, need to be fed to the animals exogenously, either orally or via ruminal cannula. For the experiment, capsules containing $0.75 \mathrm{~g}$ of $\mathrm{Cr}_{2} \mathrm{O}_{3}$ or $1 \mathrm{~g}$ of $\mathrm{TiO}_{2}$ were prepared at a local pharmacy. All cows received $15 \mathrm{~g}$ of $\mathrm{Cr}_{2} \mathrm{O}_{3}$ and $15 \mathrm{~g}$ of $\mathrm{TiO}_{2}$ daily. This dose was divided into 2 equal parts and the animals were fed the capsules (mixed with a small amount of concentrate and molasses) before receiving the rest of the meal $(0800$ and $1600 \mathrm{~h})$. The animals were dosed from $\mathrm{d} 5$ to 18 of the experimental period and had been receiving molasses with concentrate before each meal during the $14 \mathrm{~d}$ before the start of the experiment.

\section{Feces}

On d 15, all stalls were thoroughly cleaned (pressure hosed). On d 16 at $0600 \mathrm{~h}$ stalls were cleaned of what was excreted overnight and at $0800 \mathrm{~h}$ the $72-\mathrm{h}$ TFC period started. Two-person teams constantly watched all the animals, in 8-h shifts, and collected all feces immediately after excretion to avoid contamination with bedding sand or partial loss of material. Cows were slowly and carefully followed to the milking parlor to collect any fecal matter excreted during this procedure. Collected feces were placed into individual (one per cow) blue plastic containers (100 L; previously weighed empty) that were kept sealed and away from direct sunlight. At $0730 \mathrm{~h}$ of d 17 to 19, the containers were weighed and the daily RFO was recorded for each animal. Fecal matter in each container was homogenized (mixed thoroughly with a ladle) and an approximately 500-g sample was taken for each animal daily, during the sampling period. These bulk samples constituted the 72-h continuous sampling design.

Two grab sampling designs were evaluated during this study. Sampaio et al. (2011a) compared 9 different sampling design protocols and reported that 4 samples collected during daylight hours were enough to obtain a representative sample of the daily excretion profile. A commonly used design in marker studies is the 3-d sampling period with samples being taken every $9 \mathrm{~h}$.
Table 1. Chemical composition of feeds and TMR, total-tract apparent digestibility (TTAD), real fecal output (RFO), and real dry matter intake (RDMI) of TMR

\begin{tabular}{|c|c|c|c|}
\hline Item & Silage & Concentrate & TMR \\
\hline $\mathrm{DM}(\mathrm{g} / \mathrm{kg})$ & 288.4 & 822.4 & 528.7 \\
\hline $\operatorname{Ash}^{1}(\mathrm{~g} / \mathrm{kg}$ of $\mathrm{DM})$ & 43.0 & 56.9 & 49.3 \\
\hline $\mathrm{CP}^{2}(\mathrm{~g} / \mathrm{kg}$ of $\mathrm{DM})$ & 94.0 & 265.9 & 171.4 \\
\hline $\mathrm{EE}^{3}(\mathrm{~g} / \mathrm{kg}$ of $\mathrm{DM})$ & 66.0 & 127.9 & 93.9 \\
\hline $\mathrm{NDF}^{4}(\mathrm{~g} / \mathrm{kg}$ of $\mathrm{DM})$ & 560.0 & 457.6 & 535.7 \\
\hline $\mathrm{CW}^{5}(\mathrm{~g} / \mathrm{kg}$ of $\mathrm{DM})$ & 736.9 & 763.9 & 749.1 \\
\hline $\mathrm{SF}^{6}(\mathrm{~g} / \mathrm{kg}$ of $\mathrm{DM})$ & 137.4 & 306.3 & 213.4 \\
\hline $\mathrm{ADF}(\mathrm{g} / \mathrm{kg}$ of $\mathrm{DM})$ & 348.1 & 97.7 & 235.5 \\
\hline $\mathrm{iNDF}^{7}(\mathrm{~g} / \mathrm{kg}$ of $\mathrm{DM})$ & 247.2 & 29.6 & 155.7 \\
\hline $\mathrm{iADF}^{8}(\mathrm{~g} / \mathrm{kg}$ of $\mathrm{DM})$ & 160.0 & 20.0 & 99.6 \\
\hline $\mathrm{ABL}^{9}(\mathrm{~g} / \mathrm{kg}$ of $\mathrm{DM})$ & 95.8 & 13.0 & 58.5 \\
\hline Cutin (g/kg of DM) & 3.5 & 7.6 & 5.3 \\
\hline TTAD ( $\mathrm{g} / \mathrm{kg}$ of DM $)$ & - & - & 710.7 \\
\hline RFO $(\mathrm{g}$ of $\mathrm{DM} / \mathrm{d})$ & - & - & $6,900.3$ \\
\hline RDMI ( $g$ of DM/d) & - & - & $24,078.1$ \\
\hline
\end{tabular}

${ }^{1} \mathrm{Ash}\left(500^{\circ} \mathrm{C}\right)$.

${ }^{2} \mathrm{~N} \% \times 6.25$.

${ }^{3} \mathrm{EE}=$ ether extract.

${ }^{4}$ Neutral detergent soluble fiber.

${ }^{5} \mathrm{CW}=$ cell wall.

${ }^{6}$ Soluble fiber $(\mathrm{SF})=\mathrm{CW}-\mathrm{NDF}$.

${ }^{7}$ Indigestible NDF, $288 \mathrm{~h}$ in situ assay.

${ }^{8}$ Indigestible ADF, $288 \mathrm{~h}$ in situ assay.

${ }^{9} \mathrm{ABL}=$ acetyl bromide lignin.

This way, at the end of the $3 \mathrm{~d}$, the $24 \mathrm{~h}$ of a day will be represented by the various samples. Table 2 illustrates the fecal sampling design protocols used in this study.

The grab samples were collected at the same time as bulk sampling. At the end of each day, grab sample weights were added to the TFC weight. The grab sample weights varied between 50 and $500 \mathrm{~g}$ per sample. These grab samples were the composited daily and analyzed by sampling method.

\section{Chemical Analysis and Measurements}

For quantification of voluntary intake, feed supplied and feces collected between d 15 to 18, and orts collected between d 16 to 19 were measured. Samples were composited by animal and frozen at $-20^{\circ} \mathrm{C}$. Later, feces, feed, and ort samples (approximately $500 \mathrm{~g}$ ) were thawed at room temperature, oven dried at $55^{\circ} \mathrm{C}$, and processed in a MA-048 knife mill (Marconi, São Paulo, Brazil), with a 2-mm mesh screen. Preference was given

Table 2. Sampling design protocols for bulk and grab feces samples

\begin{tabular}{lll}
\hline Design & Sampling & Duration and sampling times \\
\hline $\mathrm{A}$ & Bulk $72 \mathrm{~h}$ & $72 \mathrm{~h}(\mathrm{~d} \mathrm{16-18)}$, continuous \\
$\mathrm{B}$ & Grab $9 \times 3$ & $3 \mathrm{~d}(\mathrm{~d} 16=0800,1700,0200 \mathrm{~h} ; \mathrm{d} 17=1100,2000,0500 \mathrm{~h} ; \mathrm{d} 18=1400,2300,0800 \mathrm{~h})$ \\
$\mathrm{C}$ & Grab $4 \times 4$ daylight & $4 \mathrm{~d}(\mathrm{~d} 16-19), 0800,1100,1400,1700 \mathrm{~h}$ \\
\hline
\end{tabular}


to the 2-mm screen because, according to Froidmont et al. (2008), fine grinding can cause loss of small particles (containing lignin and cutin), which would have a significant effect on our expected results.

Feed and TMR samples were analyzed for DM $\left(105^{\circ} \mathrm{C}\right.$ for $24 \mathrm{~h})$ and ash $\left(500^{\circ} \mathrm{C}\right.$ for $\left.8 \mathrm{~h}\right)$ by incineration in a muffle furnace (Marconi). Neutral detergent fiber and ADF were determined using the fiber bag procedure (Van Soest et al., 1991), with addition of heat-stable amylase and without sodium sulfite (Mertens, 2002), in a TE-149 Fiber Analyzer (Tecnal, São Paulo, Brazil). Briefly, 0.5-g samples were weighed into nonwoven textile fiber bags (25 $\mu \mathrm{m}$ pore size; Baglab, Pirassununga, $\mathrm{SP}, \mathrm{Brazil})$. The bags were heat-sealed and placed into the fiber analyzer (30 bags per batch, $10 \mathrm{~mL}$ of solution per bag) for $60 \mathrm{~min}$. After this, the bags were thoroughly washed 3 times with boiling water and dried at $105^{\circ} \mathrm{C}$, overnight.

Cell wall preparation was obtained according to the procedure proposed by Fukushima and Hatfield (2001) and later used as substrate for ABL determination in feed, orts, and feces samples, according to Fukushima and Kerley (2011). Lignin absorbance was determined with a Libra S80 spectrophotometer (Biochrom, Cambridge, United Kingdom) at a wavelength of $280 \mathrm{~nm}$. Soluble fiber was calculated as the difference between cell wall and NDF contents, composed mainly of pectin. Indigestible neutral detergent fiber and indigestible acid detergent fiber (iNDF and iADF, respectively), with ash, were obtained by weighing silage and feces $(0.5 \mathrm{~g})$, orts $(1.0 \mathrm{~g})$, and concentrate $(1.0 \mathrm{~g})$ samples into F57 bags $(25 \mu \mathrm{m}$ pore size, Ankom Technology Corp., Fairport, NY). Samples were incubated inside the rumen of a cannulated cow for $288 \mathrm{~h}$ (Casali et al., 2008; Krizsan and Huhtanen, 2013), washed with abundant water, and treated according to Van Soest and Robertson (1985) for determination of these indigestible fractions. The ABL, iNDF, and iADF content that was measured in orts samples was then discounted from the content measured in feeds to correct the ingested amount of marker.

Cutin contents in feed, TMR, orts, and feces samples were determined in nonwoven textile fiber bags according to the procedure described by R. S. Fukushima (personal communication). Briefly, DM samples are sequentially treated with neutral detergent and acid detergent solutions to obtain an acid detergent residue. Fiber bags containing acid detergent residue were treated with potassium permanganate solution $\left(\mathrm{KMnO}_{4}\right)$ to oxidize lignin and afterward treated with $72 \%$ sulfuric acid solution $\left(\mathrm{H}_{2} \mathrm{SO}_{4}\right)$ to hydrolyze cellulose, leaving behind cutin and mineral residue. Bags were dried in a forced-draft oven at $105^{\circ} \mathrm{C}$ for $12 \mathrm{~h}$ and weighed. Finally, the residue-containing bags were incinerated at $450^{\circ} \mathrm{C}$ in a muffle furnace, and cutin contents are calculated as

$$
\text { Cutin } \%=\{[\mathrm{WaH}-(\mathrm{WaI}-\mathrm{Wc})] \times 100\} \div \mathrm{SiW},
$$

where $\mathrm{WaH}=$ weight after sulfuric acid hydrolysis, WaI = weight after incineration, $\mathrm{Wc}=$ weight of crucible, and $\mathrm{SiW}=$ sample initial weight.

The cutin content that was measured in orts samples was then discounted from the content measured in feeds to correct the ingested amount of marker.

Crude protein $(\mathrm{N} \% \times 6.25)$ was determined in feed and TMR samples by the micro-Kjeldahl procedure in a TE 036/1 Nitrogen Distiller (Tecnal, São Paulo, Brazil). Ether extract content of feeds and TMR was determined by petroleum ether extraction using a XT10 Extractor (Ankom Technology Corp., Fairport, NY).

The quantification of $\mathrm{Cr}_{2} \mathrm{O}_{3}$ in feces samples was performed by visible light spectrophotometry (550 $\mathrm{nm}$ ) according to the procedure proposed by Kimura and Muller (1957) with the modifications proposed by Graner (1972). Standard samples (1 g of feces from an animal that had not received $\mathrm{Cr}_{2} \mathrm{O}_{3}$ ) containing 0 , $2,4,6,8$, and $10 \mathrm{mg}$ of chromium per $\mathrm{g}$ of $\mathrm{DM}$ were analyzed in triplicate, totaling 18 standard samples. Pure $\mathrm{Cr}_{2} \mathrm{O}_{3}$ (99\% trace metals basis; Solumix, Campinas, São Paulo, Brazil) was employed to produce the standards. The concentration of $\mathrm{Cr}_{2} \mathrm{O}_{3}$ was analyzed and compared with the added amount of $\mathrm{Cr}_{2} \mathrm{O}_{3}$. The results of the regression are shown in Figure 1.

The quantification of $\mathrm{TiO}_{2}$ in feces samples was performed by visible light spectrophotometry (410 $\mathrm{nm})$ according to Myers et al. (2004). To validate the accuracy of the $\mathrm{TiO}_{2}$ analysis, a regression equation

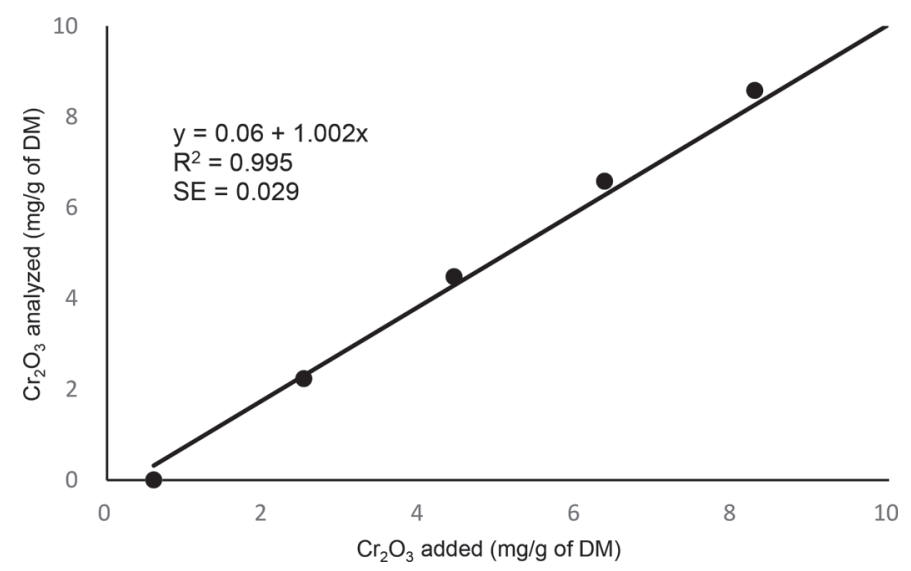

Figure 1. Relationship between $\mathrm{Cr}_{2} \mathrm{O}_{3}$ added and $\mathrm{Cr}_{2} \mathrm{O}_{3}$ analyzed in feces matrix. 


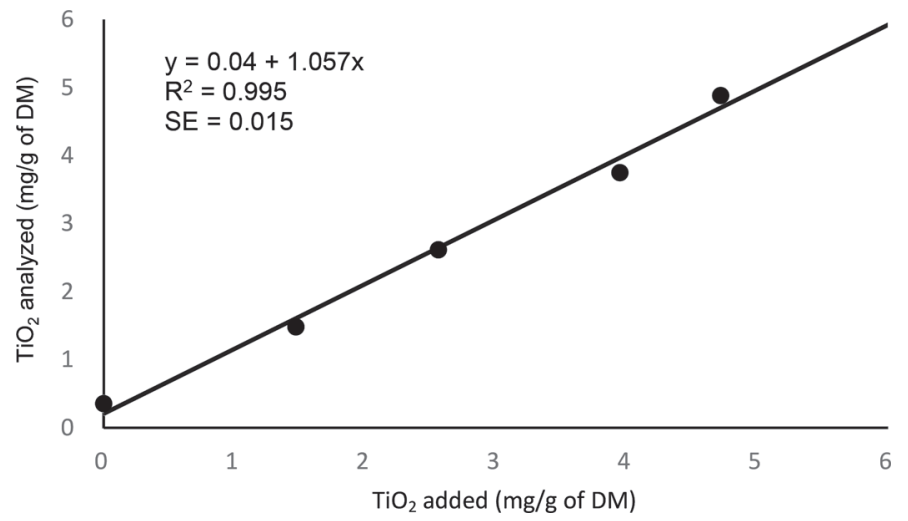

Figure 2. Relationship between $\mathrm{TiO}_{2}$ added and $\mathrm{TiO}_{2}$ analyzed in feces matrix.

was created using the method proposed by Glindemann et al. (2009). Standard samples (1 $\mathrm{g}$ of feces from an animal that had not received $\mathrm{TiO}_{2}$ ) containing $0,1,2$, $3,4,5$, and $6 \mathrm{mg}$ of titanium per $\mathrm{g}$ of $\mathrm{DM}$ were analyzed in triplicate, totaling 21 standard samples. Pure $\mathrm{TiO}_{2}$ (99.3\% trace metals basis; Dinâmica \#1093) was employed to produce the standards. The concentration of $\mathrm{TiO}_{2}$ was analyzed and compared with the added amount of $\mathrm{TiO}_{2}$. The results of the regression are shown in Figure 2.

\section{Calculations}

Real dry matter intake was calculated as daily feed offer minus daily orts (Equation [1]), and RFO was calculated as the average of $3 \mathrm{~d}$ (d 16 to 18) of TFC (24 $\mathrm{h}$ collection and daily weighing of amount excreted). Total-tract apparent digestibility was calculated as RDMI minus RFO (Equation [2]):

$$
\begin{aligned}
& \operatorname{RDMI}(\mathrm{g} / \mathrm{d})=\text { daily feed offered }(\mathrm{g} / \mathrm{d}) \\
& - \text { orts collected }(\mathrm{g} / \mathrm{d}) \\
& \operatorname{TTAD}(\mathrm{g} / \mathrm{kg} \text { of DM }) \\
& =\frac{[\operatorname{RDMI}(\mathrm{g} / \mathrm{d})-\operatorname{RFO}(\mathrm{g} / \mathrm{d})] \times 1,000}{\operatorname{RDMI}} .
\end{aligned}
$$

Equations [3] and [4] were used to estimate marker excretion and recovery rate. These equations were derived from both bulk and grab samples. The overall recovery rate of markers was calculated from the total amount of marker given (minus the amount of marker measured in orts) and the amount recovered during the fecal sampling period (d 15 to 19). Daily recovery rate of markers was calculated from d 16 to 19: marker excretion $(\mathrm{g} / \mathrm{d})=[$ fecal marker $](\mathrm{g} / \mathrm{g}) \times \operatorname{RFO}(\mathrm{g} / \mathrm{d})$,

recovery rate of the marker $=\frac{\text { marker } \operatorname{excreted}(\mathrm{g} / \mathrm{d})}{\text { marker ingested }(\mathrm{g} / \mathrm{d})}$.

Equation [5] was used to estimate FO using external markers and Equation [6] was used to estimate DMD using internal markers:

FO estimated by external marker (g of DM/d)

$$
=\frac{\text { daily marker dose }(\mathrm{g} / \mathrm{d})}{[\text { fecal marker }](\mathrm{g} / \mathrm{g} \text { of } \mathrm{DM})},
$$

DMD estimated by internal marker $(\mathrm{g} / \mathrm{kg}$ of $\mathrm{DM})$

$$
=100-\left(100 \times\left(\frac{[\text { marker in feed }](\mathrm{g} / \mathrm{g} \text { of } \mathrm{DM})}{[\text { fecal marker }](\mathrm{g} / \mathrm{g} \text { of } \mathrm{DM})}\right)\right. \text {. }
$$

Equation [7] was used to estimate total voluntary intake from FO and DMD estimates obtained by Equations [5] and [6]. Total DMI was estimated for both bulk and grab samples:

DMI estimated by markers $(\mathrm{g} / \mathrm{d})=\frac{\mathrm{FO}(\mathrm{kg} \text { of } \mathrm{DM} / \mathrm{d})}{1-\operatorname{diet} \mathrm{DMD}}$.

\section{Statistical Analysis}

Results were analyzed with SAS 9.3 (SAS Institute [1] Inc., Cary, NC), after verifying normality of residuals and homogeneity of variance. With normally distributed TTAD values and DMD estimates, a $4 \times 4$ factorial arrangement was adopted (4 markers and 4 sampling procedures) and data were analyzed using PROC MIXED, at a 0.05 significance level, according to the following model:

$$
\mathrm{Y}_{\mathrm{ijk}}=\mu+\mathrm{T}_{\mathrm{i}}+\mathrm{M}_{\mathrm{j}}+\mathrm{TM}_{\mathrm{ij}}+\mathrm{A}(\mathrm{T})_{\mathrm{k}}+\varepsilon_{\mathrm{ijk}},
$$

where $\mathrm{Y}_{\mathrm{ijk}}=$ the DMD estimated in animal $\mathrm{k}$, by marker $\mathrm{i}$, under sampling procedure $\mathrm{j} ; \mu=$ the general constant; $T_{i}=$ the fixed effect of internal marker; $M_{j}=$ the fixed effect of sampling procedure; $\mathrm{TM}_{\mathrm{ij}}=$ the interaction between internal marker $\mathrm{i}$ and sampling procedure $\mathrm{j}$ 
(fixed); $\mathrm{A}(\mathrm{T})_{\mathrm{k}}=$ the random effect of animal $\mathrm{k}$ nested to marker $\mathrm{i}$; and $\varepsilon_{\mathrm{ijk}}=$ the sampling error supposed to be normal and independently distributed.

After verifying normal distribution of RFO values and FO estimates, a $2 \times 4$ factorial arrangement was adopted (2 markers and 4 sampling procedures) and data were analyzed using PROC MIXED, at a 0.05 significance level, according to the model

$$
\mathrm{Y}_{\mathrm{xyz}}=\mu+\mathrm{T}_{\mathrm{x}}+\mathrm{M}_{\mathrm{y}}+\mathrm{TM}_{\mathrm{xy}}+\mathrm{A}(\mathrm{T})_{\mathrm{z}}+\varepsilon_{\mathrm{xyz}},
$$

where $\mathrm{Y}_{\mathrm{xyz}}=$ the $\mathrm{FO}$ estimated in animal $\mathrm{z}$, by marker $\mathrm{x}$, under sampling procedure $\mathrm{y} ; \mu=$ the general constant; $\mathrm{T}_{\mathrm{x}}=$ the fixed effect of external marker; $\mathrm{M}_{\mathrm{y}}=$ the fixed effect of sampling procedure; $\mathrm{TM}_{\mathrm{xy}}=$ the interaction between external marker $\mathrm{x}$ and sampling procedure $\mathrm{y}$ (fixed); $\mathrm{A}(\mathrm{T})_{\mathrm{z}}=$ the random effect of animal $\mathrm{z}$ nested to marker $\mathrm{x}$; and $\varepsilon_{\mathrm{xyz}}=$ the sampling error supposed to be normal and independently distributed.

Values of RDMI and DMI estimates were checked for normal distribution and an $8 \times 4$ factorial arrangement was adopted 8 marker pairs (one internal + one external) and 4 sampling procedures]. Data were analyzed using PROC MIXED, at a 0.05 significance level, according to the model

$$
\mathrm{Y}_{\mathrm{bcd}}=\mu+\mathrm{T}_{\mathrm{b}}+\mathrm{M}_{\mathrm{c}}+\mathrm{TM}_{\mathrm{bc}}+\mathrm{A}(\mathrm{T})_{\mathrm{d}}+\varepsilon_{\mathrm{bcd}},
$$

where $Y_{b c d}=$ the DMI estimated in animal $d$, by marker $\mathrm{b}$, under sampling procedure $\mathrm{c} ; \mu=$ the general constant; $\mathrm{T}_{\mathrm{b}}=$ the fixed effect of marker pair; $\mathrm{M}_{\mathrm{c}}=$ the fixed effect of sampling procedure; $\mathrm{TM}_{\mathrm{bc}}=$ the interaction between marker pair $\mathrm{b}$ and sampling procedure $\mathrm{c}$ (fixed); $\mathrm{A}(\mathrm{T})_{\mathrm{d}}=$ the random effect of animal $\mathrm{d}$ nested to marker b; and $\varepsilon_{\mathrm{bcd}}=$ the sampling error supposed to be normal and independently distributed.

Linear regression analysis and Student's paired $t$-test were used to compare estimates against real observed values (those derived from TFC) for all variables being studied.

\section{RESULTS}

Mean RDMI (average \pm SD) was $24.1 \pm 4.0 \mathrm{~kg} /$ animal per d, equivalent to $3.9 \pm 0.4 \%$ of $\mathrm{BW}$. Mean $\mathrm{RFO}$ (average $\pm \mathrm{SD}$ ) was $6.9 \pm 1.1 \mathrm{~kg}$ of $\mathrm{DM} /$ animal per d, equivalent to $1.1 \pm 0.2 \%$ of BW. The chemical composition of the feeds and TMR were in accordance with the diet formulated for the experiment. The values for TTAD (average $\pm \mathrm{SD}$ ) of $710.7 \pm 41.1 \mathrm{~g} / \mathrm{kg}$ of DM were higher than expected, as were those for ether extract (average $\pm \mathrm{SD}$ ) of $9.4 \pm 0.4 \% \mathrm{DM}$, considering the average quality of the corn silage that composed $55 \%$ of the diet.

\section{Fecal Recovery of Markers}

Mean fecal recovery (FR) of markers varied widely and are shown in Table 3. A highly significant effect for marker $(P<0.0001)$ was observed. No effect for sampling procedure $(P=0.325)$ or for the marker $\times$ sampling procedure interaction $(P=0.126)$ was detected. Cutin produced the lowest FR results among all the markers, always well under $100 \%$ for the 3 sampling procedures. In contrast, fecal recovery of $\mathrm{TiO}_{2}$ was unexpectedly high (around 200\%) independent of the sampling procedure. Indigestible $\mathrm{NDF}$ and $\mathrm{ADF}$ produced similar FR, around $150 \%$ for the 24 -h period and ABL had a FR around $100 \%$, which was similar in all sampling procedures. The FR of $\mathrm{Cr}_{2} \mathrm{O}_{3}$ differed $(P$ $=0.044)$ between the $4 \times 4$ and $9 \times 3$ grab sampling procedures, but neither one was different $(P=0.344$ and $P=0.285$, respectively) from FR of the 72-h sampling procedure.

\section{Prediction of DMD Based on Fecal Concentration of Internal Markers}

The mean DMD estimates are shown in Table 4. Significant effects for marker, sampling procedure, and a tendency on their interaction were observed $(P$ $<0.0001, P=0.003$, and $P=0.060$, respectively). Estimates of DMD from iADF and iNDF were not significantly different from TTAD, independent of the

Table 3. Twenty-four hour fecal recovery (FR; mean $\pm \mathrm{SE}$ ) of markers under 2 grab $(4 \times 4$ and $9 \times 3)$ and 1 bulk $(72 \mathrm{~h})$ fecal sampling

\begin{tabular}{|c|c|c|c|}
\hline \multirow[b]{2}{*}{ Marker $^{1}$} & \multicolumn{3}{|c|}{ Method } \\
\hline & $4 \times 4$ grab & $9 \times 3$ grab & $72 \mathrm{~h}$ bulk \\
\hline ABL & $0.98^{\mathrm{cd}} \pm 0.09$ & $0.95^{\mathrm{d}} \pm 0.08$ & $1.11^{\mathrm{c}} \pm 0.13$ \\
\hline Cutin & $0.81^{\mathrm{d}} \pm 0.14$ & $0.67^{\mathrm{e}} \pm 0.09$ & $0.80^{\mathrm{d}} \pm 0.11$ \\
\hline iADF & $1.47^{\mathrm{b}} \pm 0.08$ & $1.55^{\mathrm{b}} \pm 0.08$ & $1.60^{\mathrm{b}} \pm 0.08$ \\
\hline iNDF & $1.43^{\mathrm{b}} \pm 0.07$ & $1.50^{\mathrm{b}} \pm 0.07$ & $1.53^{\mathrm{b}} \pm 0.08$ \\
\hline $\mathrm{Cr}_{2} \mathrm{O}_{3}$ & $1.01^{\mathrm{B}, \mathrm{c}} \pm 0.06$ & $1.23^{\mathrm{A}, \mathrm{c}} \pm 0.06$ & $1.12^{\mathrm{AB}, \mathrm{c}} \pm 0.06$ \\
\hline $\mathrm{TiO}_{2}$ & $1.95^{\mathrm{a}} \pm 0.16$ & $1.99^{\mathrm{a}} \pm 0.14$ & $1.83^{\mathrm{a}} \pm 0.14$ \\
\hline
\end{tabular}
procedures

$\overline{\mathrm{A}, \mathrm{B}}$ Within a row, mean values with common uppercase superscripts are not significantly different by Fisher's LSD $(P<0.05)$.

${ }^{\mathrm{a}-\mathrm{d}}$ Within a column, mean values with common lowercase superscripts are not significantly different by Fisher's LSD $(P<0.05)$.

${ }^{1} \mathrm{ABL}=$ acetyl bromide lignin; $\mathrm{iADF}=$ indigestible $\mathrm{ADF} ; \mathrm{iNDF}=$ indigestible NDF. 
Table 4. Mean total-tract apparent digestibility (TTAD; $\mathrm{g} / \mathrm{kg}$ of $\mathrm{DM}$ ) and dry matter digestibility (DMD; $\mathrm{g} / \mathrm{kg}$ of DM) estimates derived from internal markers on 2 grab $(4 \times 4$ and $9 \times 3)$ and 1 bulk $(72 \mathrm{~h})$ fecal sampling procedures (mean $\pm \mathrm{SE}$ )

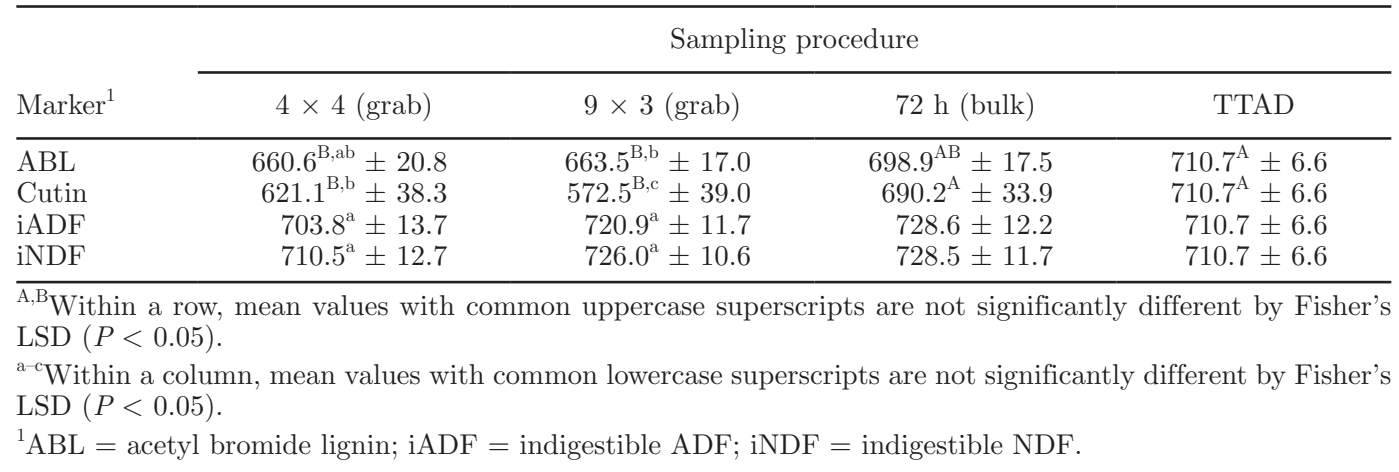

sampling procedure. Cutin and ABL estimates of DMD were only accurate under the 72 -h sampling procedure $(P=0.479$ and $P=0.654$, respectively).

\section{Prediction of FO Based on Fecal Concentration of External Markers}

The mean FO estimates are shown in Table 5. Significant effects for marker, sampling procedure, and their interaction were observed $(P<0.0001, P=0.002$, and $P=0.006$, respectively). Estimates for FO produced by $\mathrm{TiO}_{2}$ were not accurate when compared with RFO. Estimates of $\mathrm{FO}$ from $\mathrm{Cr}_{2} \mathrm{O}_{3}$ concentrations were only accurate for the $9 \times 3$ and 72 -h fecal sampling procedures $(P=0.206, P=0.306$, respectively $)$.

\section{Prediction of DMI Based on Internal and External Marker Pairs}

The mean DMI estimates are shown in Table 6. Highly significant effects for marker and sampling procedure $(P<0.0001)$ were observed, yet no effect $(P=0.447)$ for their interaction was detected. Most DMI estimates by $\mathrm{TiO}_{2}$ differed substantially from RFO under all sampling regimens. When $\mathrm{TiO}_{2}$ was paired with iNDF and
iADF, under the 72-h sampling procedure, estimates were accurate $(P=0.145$ and $P=0.146$, respectively), and the same was observed when it was paired with cutin under the $4 \times 4$ sampling procedure $(P=0.080)$. Estimates of DMI from $\mathrm{Cr}_{2} \mathrm{O}_{3}$ paired with any of the internal markers were mostly accurate. When paired with iADF, DMI estimates from $\mathrm{Cr}_{2} \mathrm{O}_{3}$ were not detected as different from RDMI independently of the sampling procedure used.

\section{DISCUSSION}

\section{Fecal Recovery of Markers}

Fecal recovery varied widely among markers and ranged from 0.67 to $0.81 \mathrm{~g} / \mathrm{g}$ of $\mathrm{DM}$ for cutin to 1.83 to $1.99 \mathrm{~g} / \mathrm{g}$ of $\mathrm{DM}$ for $\mathrm{TiO}_{2}$. No reports were found on the use of cutin as a marker in ruminant digestion studies and therefore our data are novel to this field of research. Siqueira et al. (2009) used cutin as a DMD marker in horses consuming 4 different diets and observed FR around $1.51 \mathrm{~g} / \mathrm{g}$ of DM. The FR in horses was almost double of what our study observed for ruminants. Obvious and known differences in digestive anatomy and physiology of both species could account, at least partially, for these FR differences.

Table 5. Mean real fecal output (RFO; $g$ of DM/d) and fecal output (FO; $g$ of DM/d) estimates derived from external markers on 2 grab $(4 \times 4$ and $9 \times 3)$ and 1 bulk $(72 \mathrm{~h})$ fecal sampling procedures (mean $\pm \mathrm{SE})$

\begin{tabular}{lcccc}
\hline & \multicolumn{4}{c}{ Sampling procedure } \\
\cline { 2 - 5 } Marker & $4 \times 4$ grab & $9 \times 3$ grab & 72 h bulk & RFO \\
\hline $\mathrm{Cr}_{2} \mathrm{O}_{3}$ & $7,971.0^{\mathrm{A}, \mathrm{a}} \pm 286.2$ & $6,455.1^{\mathrm{C}, \mathrm{a}} \pm 208.3$ & $7,260.1^{\mathrm{B}, \mathrm{a}} \pm 293.3$ & $6,900.3^{\mathrm{BC}} \pm 204.9$ \\
$\mathrm{TiO}_{2}$ & $5,015.3^{\mathrm{B}, \mathrm{b}} \pm 223.3$ & $4,823.8^{\mathrm{B}, \mathrm{b}} \pm 202.2$ & $5,403.6^{\mathrm{B}, \mathrm{b}} \pm 307.5$ & $6,900.3^{\mathrm{A}} \pm 204.9$ \\
\hline${ }^{\mathrm{A}-\mathrm{C}}$ Within a row, mean values with common uppercase superscripts are not significantly different by Fisher's \\
LSD $(P<0.05)$. \\
a,b Within a column, mean values with common lowercase superscripts are not significantly different by Fisher's \\
LSD $(P<0.05)$.
\end{tabular}


Liquid and solid phase stratification of contents in the rumen compared with the herbivore monogastric stomach are totally different. The differences in these phases will directly influence how the cutin particle interacts and binds to digesta around it. This interaction will, in turn, determine the retention time $\left(T_{R}\right)$ and passage rate $\left(Q_{P}\right)$ of cutin and ultimately affect what fraction of ingested cutin will be excreted in feces over a $24-\mathrm{h}$ period. Njaa (1961) reported that mean FR less than one could be attributed to inaccuracy of the analysis. Because cutin makes up such a small fraction of DM, gravimetric errors tend to be more likely to happen.

Several authors (Kotb and Luckey, 1972; Fahey and Jung, 1983) have long described what the properties of the ideal marker should be. Among these properties, one of the most important ones is that the daily ingested/dosed amount of marker can be totally recovered in feces within a 24-h period. Many studies have been conducted over the last 3 decades using $\mathrm{TiO}_{2}$ and the FR observed for it has been around $100 \%$. Based on these findings, the routine use of $\mathrm{TiO}_{2}$ in ruminal digestion trails has been suggested. Our findings do not support the use of $\mathrm{TiO}_{2}$ as an external marker to estimate FO in ruminants because we observed FR that ranged from 1.83 to $1.99 \mathrm{~g} / \mathrm{g}$ of DM. These findings were contrary to those of Brandt and Allam (1987), Hafez et al. (1988), and Titgemeyer et al. (2001), who observed mean FR for $\mathrm{TiO}_{2}$ of 0.96 to 0.99 in sheep, and 0.96 to 1.02 and 0.90 to 0.95 in dairy cattle, respectively. Glindemann et al. (2009) found FR higher than 1 and attributed this to possible ingestion of soil that contained $\mathrm{TiO}_{2}$ and therefore would increase the fecal concentration. Our diet was composed of corn silage and concentrate, and the animals were kept in stalls with concrete flooring, so the risk of soil contamination was low.
Mean FR of $\mathrm{Cr}_{2} \mathrm{O}_{3}$ varied from 1.01 to $1.23 \mathrm{~g} / \mathrm{g}$ of DM in this study. Benvenutti et al. (2014) worked with Brahman steers fed leafy or stemmy grass hay and observed FR of 0.92 to $1.03 \mathrm{~g} / \mathrm{g}$ of DM. Because $\mathrm{Cr}_{2} \mathrm{O}_{3}$ has been widely used as a marker in digestions studies, various FR have been reported for it: in horses, FR ranged from 0.712 to $1.031 \mathrm{~g} / \mathrm{g}$ of DM (Oliveira et al., 2003; Siqueira et al., 2009; Lanzetta et al., 2009), in sheep from 0.80 to $0.92 \mathrm{~g} / \mathrm{g}$ of $\mathrm{DM}$ (Rodrigues et al., 2010), in dairy cattle from 0.87 to $0.89 \mathrm{~g} / \mathrm{g}$ of DM (Delagarde et al., 2000), and in steers from 0.85 to 1.05 g/g of DM (Sampaio et al., 2011b). Paixão et al. (2007) fed $\mathrm{Cr}_{2} \mathrm{O}_{3}$ to steers and observed total fecal recovery of the administered dose. Our results are in accordance to their findings and suggest that $\mathrm{Cr}_{2} \mathrm{O}_{3}$ is an appropriate external marker for estimating $\mathrm{FO}$ in cattle.

Lignin, determined as ADL, has been used as an internal marker for digestibility studies and is considered indigestible because no microbial or mammalian enzymes can degrade it (Van Soest, 1994). The ADL method has received criticism over the years because it can measure cutin and Maillard's compounds as being lignin. Additionally, this method has also been criticized because of lignin solubilization or destruction during hydrolysis with $72 \% \mathrm{H}_{2} \mathrm{SO}_{4}$ solution. According to Lowry et al. (1994), this loss of lignin during analysis can be upward of $50 \%$ in some tropical grasses. Because of this, lignin had not been extensively used as an internal marker and the few published reports account for underestimation of DMD. Goachet et al. (2009) used ADL to estimate digestibility coefficients in horses and observed FR of 0.90 and $0.86 \mathrm{~g} / \mathrm{g}$ of DM for 3 and 4 d of fecal sampling, respectively. This study measured lignin as ABL, a procedure in which no lignin loss occurs during sample preparation and that is less subject

Table 6. Mean real dry matter intake (RDMI; $g$ of DM/d) and DMI ( $\mathrm{g}$ of DM/d) estimates derived from 1 internal +1 external marker pairs on 2 grab $(4 \times 4$ and $9 \times 3)$ and 1 bulk $(72 \mathrm{~h})$ fecal sampling procedures $($ mean $\pm \mathrm{SE})$

\begin{tabular}{lccrr}
\hline \multicolumn{5}{c}{ Sampling procedure } \\
\cline { 2 - 5 } Marker $^{1}$ & $4 \times 4$ grab & $9 \times 3$ grab & 72 h bulk & \multicolumn{1}{c}{ RDMI } \\
\cline { 2 - 5 } $\mathrm{Cr}_{2} \mathrm{O}_{3}$ & $26,381^{\mathrm{A}} \pm 1,816$ & $21,521^{\mathrm{B}} \pm 1,881$ & $26,586^{\mathrm{A}} \pm 1,724$ & $24,078^{\mathrm{AB}} \pm 633$ \\
$\mathrm{ABL}$ & $28,559^{\mathrm{A}} \pm 4,497$ & $19,039^{\mathrm{B}} \pm 1,978$ & $25,345^{\mathrm{A}} \pm 3,839$ & $24,078^{\mathrm{A}} \pm 633$ \\
$\mathrm{Cutin}$ & $28,259 \pm 1,394$ & $24,435 \pm 1,423$ & $28,116 \pm 1,634$ & $24,078 \pm 633$ \\
$\mathrm{iADF}$ & $28,712^{\mathrm{A}} \pm 1,340$ & $24,626^{\mathrm{AB}} \pm 1,335$ & $28,046^{\mathrm{AB}} \pm 1,621$ & $24,078^{\mathrm{B}} \pm 633$ \\
$\mathrm{iNDF}$ & $16,656^{\mathrm{B}} \pm 1,231$ & $15,707^{\mathrm{B}} \pm 1,126$ & $19,726^{\mathrm{AB}} \pm 1,398$ & $24,078^{\mathrm{A}} \pm 633$ \\
$\mathrm{TiO}_{2}$ & $19,661^{\mathrm{AB}} \pm 765$ & $13,799^{\mathrm{C}} \pm 1,461$ & $17,245^{\mathrm{BC}} \pm 1,951$ & $24,078^{\mathrm{A}} \pm 633$ \\
$\mathrm{ABL}$ & $17,793^{\mathrm{B}} \pm 985$ & $17,967^{\mathrm{B}} \pm 896$ & $20,411^{\mathrm{AB}} \pm 1,111$ & $24,078^{\mathrm{A}} \pm 633$ \\
$\mathrm{Cutin}$ & $18,158^{\mathrm{B}} \pm 1,008$ & $18,170^{\mathrm{B}} \pm 853$ & $20,406^{\mathrm{AB}} \pm 1,126$ & $24,078^{\mathrm{A}} \pm 633$ \\
$\mathrm{iADF}$ & $\mathrm{iNDF}$ & &
\end{tabular}

${ }^{\mathrm{A}-\mathrm{C}}$ Within a row, mean values with common uppercase superscripts are not significantly different by Fisher's LSD $(P<0.05)$.

${ }^{1} \mathrm{ABL}=$ acetyl bromide lignin; $\mathrm{iADF}=$ indigestible $\mathrm{ADF} ; \mathrm{iNDF}=$ indigestible $\mathrm{NDF}$. 
to gravimetric errors because of its spectrophotometric nature. Mean ABL FR ranged from 0.95 to $1.11 \mathrm{~g} / \mathrm{g}$ of DM in our study, with the lower values corresponding to grab sampling procedures. These results suggest that fecal recovery of lignin is complete when measured by $\mathrm{ABL}$ and that it is an appropriate internal marker for estimating DMD in cattle.

Indigestible neutral detergent and acid detergent fibers are 2 of the most extensively used internal markers today. Mean FR ranging from 0.50 to 1.21 (Barros et al., 2009; Kozloski et al., 2009; Rodrigues et. al., 2010; Sampaio et al., 2011b; Lee and Hristov, 2013) and from 0.80 to $1.21 \mathrm{~g} / \mathrm{g}$ of DM (Oliveira Júnior et al., 2004; Rodrigues et al., 2010; Sampaio et al., 2011b) for iNDF and iADF, respectively. Oliveira et al. (2003) worked with horses and observed FR of 1.08 to $1.34 \mathrm{~g} / \mathrm{g}$ of DM and up to $1.54 \mathrm{~g} / \mathrm{g}$ of DM for iNDF and iADF, respectively. In this study, mean FR for iNDF and iADF were 1.43 to $1.53 \mathrm{~g} / \mathrm{g}$ of $\mathrm{DM}$ and 1.47 to $1.60 \mathrm{~g} / \mathrm{g}$ of DM, respectively. These results were higher than expected and partially agree with previous findings of other authors. The disparity of results for different experiments is, at least in part, due to differences in incubation time of the samples for obtaining the fibrous fractions. Our study followed the procedure proposed by Krizsan and Huhtanen (2013) who compared various incubation times $(144,240$, and $288 \mathrm{~h})$ and reported that at least $12 \mathrm{~d}$ of incubation were necessary to isolate the completely indigestible fiber pool in feeds fed to dairy cows. The results in this study suggest that iNDF and iADF would be adequate internal markers for ruminant digestion studies because of accurate DMD estimates. Although this is true, RFO need to be determined to correct FR, which tended to be overestimated in our study.

\section{Prediction of DMD Based on Fecal Concentration of Internal Markers}

Values for DMD were underestimated and differed significantly from TTAD when grab sampling procedures and ABL or cutin were used. When fecal concentration was measured in bulk samples, both markers produced accurate DMD estimates in comparison to TTAD. Cutin is not a part of lignin, but it is measured as such by the ADL method. A possible explanation for the low DMD estimates produced by these 2 markers under the grab sampling procedures would be their low concentration in both diet and feces samples. Lower concentrations make chemical analysis less reliable because of increased difficulty to detect differences in such small amounts of residue that are left behind for weighing after the procedures are performed. In this study, lignin was measured as ABL and thus gravimetric-related issues would not be a problem. The cutin procedure that is being proposed is gravimetric and subject to these limitations. When bulk sampling was used, both markers produced accurate DMD estimates. From our observations, neither ABL or cutin could be suggested as accurate internal makers for determination of DMD in dairy cows if grab sampling procedures were to be used. With the use of bulk sampling procedures, these 2 markers deserve further attention to better understand how they behave. From what we know after researching the literature of the subject, ABL or cutin had not been used in ruminant digestion studies, and therefore more research is necessary before discarding them as possible markers.

Mean DMD estimates produced by iNDF and iADF fecal concentrations did not differ from TTAD under any of the sampling procedures. Estimates were not different between the 2 indigestible fractions when compared within the same sampling procedure, evidencing the close relationship between both fibrous fractions. Using animals on pasture, Detmann et al. (2001) reported more accurate DMD estimates when using iNDF compared with iADF. Berchielli et al. (2005) reported conflicting results when using these indigestible fractions, in response to the incubation procedure as was mentioned before when discussing FR. With heifers fed fresh sugar-cane iNDF produced more accurate DMD estimates than iADF, but when corn silage was fed to dairy cows, iADF estimates were more accurate than those of iNDF (Ferreira et al., 2008). Our findings suggest that both iNDF and iADF are suitable internal markers for estimating DMD.

\section{Prediction of FO Based on Fecal Concentration of External Markers}

Both $\mathrm{Cr}_{2} \mathrm{O}_{3}$ and $\mathrm{TiO}_{2}$ were unable to produce accurate FO estimates when compared with RFO values. Under the 72-h bulk sampling procedure, $\mathrm{Cr}_{2} \mathrm{O}_{3}$ estimates did not significantly differ $(P=0.306)$ from RFO, with a mean estimate bias (residual error) of $5 \%$. Fecal recovery of $\mathrm{Cr}_{2} \mathrm{O}_{3}$, under the $4 \times 4$ grab sampling procedure was $100 \%$, and therefore, overestimated FO was unexpected. No consistency for FO was observed for $\mathrm{Cr}_{2} \mathrm{O}_{3}$ estimates as values were overestimated on $4 \times$ 4 grab sampling, no difference was observed when 72-h bulk sampling was used, and underestimation occurred under $9 \times 3$ grab sampling. When comparing $\mathrm{Cr}_{2} \mathrm{O}_{3}$ and $\mathrm{TiO}_{2}$ in steers, Titgemeyer et al. (2001) observed that both markers significantly underestimated FO. Delagarde et al. (2000) reported accurate FO estimates, derived both from bulk and grab sampling procedures, 
positively correlated with RFO $\left(\mathrm{R}^{2}\right.$ from 0.86 to 0.96$)$ when using $\mathrm{Cr}_{2} \mathrm{O}_{3}$ as a marker in dairy cows. A more recent study that fed $\mathrm{Cr}_{2} \mathrm{O}_{3}$ to steers reported that FO estimates from grab samples were significantly higher than RFO (Benvenutti et al., 2014). Our results suggest that $\mathrm{Cr}_{2} \mathrm{O}_{3}$ could be used as a marker for estimating FO, but because FR differs from $100 \%$, TFC is needed and the best results derive from the 72-h bulk sampling procedure.

During the last decade or so, $\mathrm{TiO}_{2}$ has received increasing attention by researchers in response to the potential health threats that have been attributed to $\mathrm{Cr}_{2} \mathrm{O}_{3}$ (Myers et al., 2006). Studies have reported that $\mathrm{FO}$ estimates are overestimated, not significantly different from RFO (Titgemeyer et al., 2001), or underestimated (Glindemann et al., 2009). The variety of results appear to be caused by differences in FR, which directly affects the FO estimates. In our study, all of the $\mathrm{TiO}_{2}$-derived $\mathrm{FO}$ estimates were significantly underestimated, under all sampling procedures, when compared with RFO. This is a reflection of the unusually high FR observed in our experiment because higher than $100 \%$ FR lead to lower FO estimates.

\section{Prediction of DMI Based on Internal and External Marker Pairs}

Estimates of DMI varied widely among marker pairs and sampling procedures. Only the $\mathrm{Cr}_{2} \mathrm{O}_{3}+\mathrm{iADF}$ pair produced accurate DMI estimates under all the sampling procedures. Not significantly different DMI estimates were also observed for $\mathrm{Cr}_{2} \mathrm{O}_{3}+$ cutin under $4 \times 4$ grab and 72-h bulk sampling, as well as for $\mathrm{Cr}_{2} \mathrm{O}_{3}+\mathrm{iNDF}$ under $9 \times 3$ grab and 72 -h bulk sampling procedures. Estimates of DMI for the $\mathrm{Cr}_{2} \mathrm{O}_{3}+\mathrm{ABL}$ pair did not differ significantly from RDMI, but the observed values were different between the sampling methods. Also, although not significantly different from a statistical point of view, $\mathrm{Cr}_{2} \mathrm{O}_{3}+\mathrm{ABL}$ DMI estimates differed by an average of $2,456 \mathrm{~g} / \mathrm{d}$ when compared with RDMI. This difference is equivalent to \pm 10 percentage units error in DMI estimates, which may be manageable for practical situations but not acceptable for research studies.

When $\mathrm{TiO}_{2}$ was paired with internal markers, accurate DMI estimates were only obtained under $4 \times 4$ grab sampling for cutin and under 72-h bulk sampling for ABL, iADF, and iNDF. Once again, although estimates were "accurate," the mean difference was 4,027 $\mathrm{g} / \mathrm{d}$ or 17 percentage units less than RDMI. This much of a difference would not be acceptable under any conditions.

Previous studies with $\mathrm{TiO}_{2}$ (Titgemeyer et al., 2001) and $\mathrm{Cr}_{2} \mathrm{O}_{3}$ (Rodrigues et al., 2010; Benvenutti et al.,
2014) observed that DMI estimates were lower than or equal to RDMI for these markers, respectively. In their studies, the authors used each marker to estimate both DMD and FO to estimate DMI from these values. What they reported as the main cause for the inaccuracy of DMI estimates was FR different than $100 \%$, which resulted in under or over estimation of FO. The higher the FR, the lower FO estimates that will be obtained and vice versa. Given an accurate DMD estimate (or TTAD), if FO is underestimated then DMI will also be lower than RDMI. The same thing happens when DMD is underestimated at a given or accurate FO (or RFO). The degree of recovery of these markers has been variable (Berchielli et al., 2005; Rodrigues et al., 2010), and this happens because these fractions do not constitute uniform chemical units that are constant throughout feeds.

The results of our study were in accordance with the observations of the above-mentioned authors. Almost all $\mathrm{TiO}_{2}$ pairs derived estimates were lower than RDMI, and this can be explained by the unexpectedly higher FR for this external marker. Then, when these FO estimates were paired with underestimated DMD estimates from the internal markers, the error effect was additive. On the contrary, when estimates from $\mathrm{Cr}_{2} \mathrm{O}_{3}$ pairs were used, the errors seem to cancel each other out, as generally FO was a little overestimated and DMD estimates were lower than TTAD or more accurate (iNDF and iADF).

\section{CONCLUSIONS}

In dairy cows fed a corn silage-based diet with $45 \%$ concentrate, the average $\mathrm{FR}$ of $\mathrm{TiO}_{2}$ was higher than FR of $\mathrm{Cr}_{2} \mathrm{O}_{3}$ and both FR were more than unity. With internal markers, ABL and cutin FR was lower than unity and average FR for indigestible NDF and ADF was 1.5. The FR was unaffected by the fecal sampling procedure and appears to be an intrinsic property of each molecule and how it interacts with digesta. Of the 2 external markers, only $\mathrm{Cr}_{2} \mathrm{O}_{3}$ produced accurate FO estimates and the same happened to DMD when iNDF and iADF were used. Estimates for DMD and FO were affected by sampling procedure; 72-h bulk consistently produced accurate results. The grab sampling procedures were accurate when using either of the indigestible fibers (iNDF or iADF) to estimate DMD. As a result of these observations, we can only recommend grab sampling procedures when concomitant TFC is performed on at least one animal per treatment to determine FR. We can conclude that $\mathrm{Cr}_{2} \mathrm{O}_{3}$ is a suitable marker for estimating $\mathrm{FO}$ and that iNDF and $\mathrm{ADDF}$ are adequate for estimating DMD. Moreover, the $\mathrm{Cr}_{2} \mathrm{O}_{3}+\mathrm{iADF}$ marker pair produces accurate DMI 
estimates and deserves further attention for research in ruminant nutrition studies.

\section{ACKNOWLEDGMENTS}

The authors are grateful to Fundação de Amparo à Pesquisa do Estado de São Paulo (FAPESP; Brazil) for funding this study (research grant number 2013/074300 ) and graduate student fellowships from Coordenação de Aperfeiçoamento de Pessoal de Nível Superior (CAPES; Brazil).

\section{REFERENCES}

Barros, E. D., C. D. A. Fontes, E. Detmann, R. A. M. Vieira, L. T. Henriques, and A. M. Fernandes. 2009. Vícios na estimação da excreção fecal utilizando indicadores internos e óxido crômico em ensaios de digestão com ruminantes. Rev. Bras. Zootec. 38:20152020.

Benvenutti, M. A., D. B. Coates, J. Bindelle, D. P. Poppi, and I. J. Gordon. 2014. Can fecal markers detect a short term reduction in forage intake by cattle? Anim. Feed Sci. Technol. 194:44-57.

Berchielli, T. T., S. G. Oliveira, and A. V. Garcia. 2005. Aplicação de técnicas para estudos de ingestão, composição da dieta e digestibilidade. Arch. Vet. Sci. 10:29-40.

Brandt, M., and S. M. Allam. 1987. Analytik von Titandioxid im Darminhalt und Kot nach Kjeldahlaufschluß. Arch. Anim. Nutr. $37: 453-454$.

Casali, A. O., E. Detmann, S. C. Valadares Filho, J. C. Pereira, L. T. Henriques, S. G. Freitas, and M. F. Paulino. 2008. Influência do tempo de incubação e do tamanho de partículas sobre os teores de compostos indigestíveis em alimentos e fezes bovinas obtidos por procedimentos in situ. Rev. Bras. Zootec. 37:335-342.

Costa, L. T., F. F. Silva, C. M. Veloso, A. J. V. Pires, A. L. Rocha Neto, F. B. L. Mendes, E. S. O. Rodrigues, and V. L. Silva. 2011. Análise econômica da adição de níveis crescentes de concentrado em dietas para vacas leiteiras mestiças alimentadas com cana-deaçúcar. Rev. Bras. Zootec. 11:1155-1162.

Delagarde, R., J. L. Peyraud, and L. Delaby. 2000. Influence of herbage allowance on intake and behavior of dairy cows grazing perennial ryegrass swards in autumn. Pages 101-102 in Grazing Management, Occasional Symposium. No. 34. A. J. Rook and P. D. Penning, ed. The British Grassland Society, UK.

Detmann, E., M. F. Paulino, J. T. Zervoudakis, S. C. Valadares Filho, R. F. Euclydes, R. D. P. Lana, and D. D. Queiroz. 2001. Cromo e indicadores internos na determinação do consumo de novilhos mestiços, suplementados, a pasto. Rev. Bras. Zootec. 30:1600-1609.

Fahey, G. C., and H. G. Jung. 1983. Lignin as a marker in digestion studies: A review. J. Anim. Sci. 57:220-225.

Ferreira, M. A., S. C. Valadares Filho, and M. I. Marcondes. 2008 Consumo Individual de Matéria Seca Estimado em Bovinos de Corte e Leite Alimentados em Grupos. 1. Avaliação de Indicadores. Rev. Bras. de Zootec.

Froidmont, E., M. Bonnet, R. Oger, V. Decruyenaere, J. Romée, Y. Beckers, and N. Bartiaux-Thill. 2008. Influence of the grinding level and extrusion on the nutritional value of lupin seed (Lupinus albus) for cattle in the context of the Dutch protein evaluation system. Anim. Feed Sci. Technol. 142:59-73.

Fukushima, R. S., and R. D. Hatfield. 2001. Extraction and isolation of lignin for utilization as a standard to determine lignin concentration using the acetyl bromide spectrophotometric method. J. Agric. Food Chem. 49:3133-3139.

Fukushima, R. S., and M. S. Kerley. 2011. Use of lignin extracted from different plant sources as standards in the spectrophotometric acetyl bromide lignin method. J. Agric. Food Chem. 59:3505-3509.
Glindemann, T., B. M. Tas, C. Wang, S. Alvers, and A. Susenbeth. 2009. Evaluation of titanium dioxide as an inert marker for estimating fecal excretion in grazing sheep. Anim. Feed Sci. Technol. 152:186-197.

Goachet, A. G., C. Philippeau, M. Varloud, and V. Juliand. 2009. Adaptations to standard approaches for measuring total tract apparent digestibility and gastro-intestinal retention time in horses in training. Anim. Feed Sci. Technol. 152:141-151.

Graner, C. A. F. 1972. Determinação do crômio pelo método colorimétrico da $\sigma$-difenilcarbazida. 112f. Dissertação (Mestrado em Zootecnia). Faculdade de Ciências Médicas e Biológicas/Universidade Estadual Paulista, Botucatu.

Hafez, S., W. Junge, and E. Kalm. 1988. Schatzung der verdaulichkeit mit einer indicator-methode bei milchkuhen im vergleich zum hohenheimer-futterwert-test. Arch. Tierernahr. 38:929-945.

Kimura, F. T., and V. L. Muller. 1957. Improved determination of chromic oxide in cow feed and feces. J. Agric. Food Chem. 5:216.

Kotb, A. R., and T. D. Luckey. 1972. Markers in nutrition. Nutr. Abstr. Rev. 42:813-845.

Kozloski, G. V., F. R. Mesquista, T. P. Alves, D. S. Castagnino, C. M. Stefanello, and L. M. D. Sanchez. 2009. Avaliação do uso de frações indigestíveis do alimento como indicadores internos de digestibilidade em ovinos. Rev. Bras. Zootec. 38:1819-1823.

Krizsan, S. J., and P. Huhtanen. 2013. Effect of diet composition and incubation time on feed indigestible neutral detergent fiber concentration in dairy cows. J. Dairy Sci. 96:1715-1726.

Langlands, J. P., J. L. Corbett, I. McDonald, and G. W. Reid. 1963. Estimation of the faeces output of grazing animals from the concentration of chromium sesquioxide in a sample of faeces. Br. J. Nutr. 17:211-218.

Lanzetta, V. A. S., A. S. C. Rezende, E. O. S. Saliba, A. M. Q. Lana N. M. Rodriguez, and P. C. B. Moss. 2009. Validation of Lipe ${ }^{\mathrm{TM}}$ as method to evaluate the apparent digestibility of nutrients in equines. Rev. Bras. Zootec. 38:69-74.

Lee, C., and A. N. Hristov. 2013. Short communication: Evaluation of acid-insoluble ash and indigestible neutral detergent fiber as total-tract digestibility markers in dairy cows fed corn-silage based diets. J. Dairy Sci. 96:5295-5299.

Lowry, J. B., L. L. Conlan, A. C. Schlink, and C. S. McSweeney. 1994. Acid detergent dispersible lignin in tropical grasses. J. Sci. Food Agric. 65:41-49.

Merchen, N. R. 1993. Digestion, absortion and excretion in ruminants. Pages 172-201 in The Ruminant Animal Digestive Physiology and Nutrition. 4th ed. D. C. Church, ed. O\&B Books, Corvallis, OR.

Mertens, D. R. 2002. Gravimetric determination of amylase-treated neutral detergent fiber in feeds with refluxing in beakers or crucibles: Collaborative study. J. AOAC Int. 85:1217-1240.

Myers, W. D., P. A. Ludden, V. Nayigihubu, and B. W. Hess. 2006 Excretion patterns of titanium dioxide and chromic oxide in duodenal digesta and feces of ewes. Small Rumin. Res. 63:135-141.

Myers, W. D., P. A. Ludden, V. Nayigihugu, and B. W. Hess. 2004 Technical Note: A procedure for the preparation and quantitative analysis of samples for titanium dioxide. J. Anim. Sci. 82:179-183.

Njaa, L. R. 1961. Determination of protein digestibility with titanium dioxide as indicator substance. Acta Agric. Scandinavica 11:227241.

Oliveira, C. A. A., F. Q. Almeida, S. C. Valadares Filho, A. A. Vieira, M. I. V. Almeida, A. Corassa, B. A. Lopes, and R. Macedo. 2003. Estimativa da digestibilidade aparente de nutrientes em dietas para equinos com uso de oxido crômico e indicadores internos. Rev. Bras. Zootec. 32:1681-1689.

Oliveira Júnior, R. C., A. V. Pires, J. J. R. Fernandes, I. Susin, F. A. P. Santos, V. F. Nascimento Filho, and F. C. Araujo. 2004. Avaliação de marcadores para estimar a digestibilidade dos nutrientes em novilhos nelore alimentados com dietas contendo alto teor de concentrado e fontes nitrogenadas. Rev. Bras. Zootec. 3:749-758.

Paixão, M. L., S. C. Valadares Filho, M. I. Leão, P. R. Cecon, M I. Marcondes, P. A. Silva, and M. G. D. S. Pina. 2007. Variação diária na excreção de indicadores interno (FDAi) e externo. Rev. Bras. Zootec. 36:739-747. 
Poppi, D. P., T. P. Hughes, and P. J. L'huillier. 1987. Intake of pasture by grazing ruminants. Pages 55-64 in Livestock Feeding at Pasture. A. M. Nicol, ed. New Zealand Society of Animal Production, Hamilton. Occasional Publication, 10.

Rodrigues, P. H. M., R. C. Gomes, R. F. Siqueira, P. M. Meyer, and R. R. Rodrigues. 2010. Acurácia, precisão e robustez das estimativas da digestibilidade aparente da matéria seca determinada com o uso de indicadores em ovinos. Rev. Bras. Zootec. 39:1118-1126.

Sampaio, C. B., E. Detmann, T. N. P. Valente, V. A. C. Costa, S. C. Valadares Filho, and A. C. Queiroz. 2011a. Fecal excretion patterns and short term bias of internal and external markers in a digestion assay with cattle. Rev. Bras. Zootec. 40:657-665.

Sampaio, C. B., E. Detmann, T. N. P. Valente, M. A. Souza, S. C. Valadares Filho, and M. F. Paulino. 2011b. Evaluation of fecal recovering and long term bias of internal and external markers in a digestion assay with cattle. Rev. Bras. Zootec. 40:174-182.

Schneider, B. H., and W. P. Flatt. 1975. The Evaluation of Feeds Through Digestibility Experiments. The University of Georgia Press, Athens.
Silva, R. R., A. F. Magalhães, G. G. P. Carvalho, F. F. Silva, I. N. Prado, I. L. Franco, C. M. Veloso, and M. A. Chaves. 2004. Comportamento ingestivo de novilhas mestiças de holandês suplementadas em pastejo de brachiaria decumbes: Aspectos metodológicos. Rev. Elec. Vet. 5:1-7.

Siqueira, R. F., R. C. Gomes, P. H. Rodrigues, R. S. Fukushima, and A. A. O. Gobesso. 2009. Uso da cutina na estimativa da digestibilidade aparente de dietas para equinos. Arq. Bras.de Medicina Veterin. Zootec. 61:1373-1381.

Titgemeyer, E. C., C. K. Armendariz, D. J. Bindel, R. H. Greenwood, and C. A. Loest. 2001. Evaluation of titanium dioxide as a digestibility marker for cattle. J. Anim. Sci. 79:1059-1063.

Van Soest, P. J. 1994. Nutritional Ecology of the Ruminant. 2nd ed. Cornell University Press, Ithaca, NY.

Van Soest, P. J., and J. B. Robertson. 1985. Analysis of forages and fibrous foods. Cornell University Press, Ithaca, NY.

Van Soest, P. J., J. B. Robertson, and B. A. Lewis. 1991. Methods for dietary fiber, neutral detergent fiber, and nonstarch polysaccharides in relation to animal nutrition. J. Dairy Sci. 74:3583-3597. 